\title{
PERCEPTIVE CHANGES IN ENDURANCE ATHLETES DURING SOCIAL ISOLATION DUE TO COVID-19
}

\author{
MUDANÇAS PERCEPTIVAS EM ATLETAS DE RESISTÊNCIA DURANTEISOLAMENTO SOCIAL \\ DEVIDOA COVID-19
}

SPECIAL ARTICLE

ARTIGO ESPECIAL

ARTICULO ESPECIAL

\section{CAMBIOS PERCEPTIVOS EN ATLETAS DERESISTENCIA DURANTE AISLAMIENTO SOCIAL DEBIDO}

\author{
ALACOVID-19
}

\begin{abstract}
Flávio Ricardo Guilherme $e^{1,2,3,4}$ (ID) (Physical Education Professional)

Matheus Amarante do

Nascimento 2,5 (iD)

(Physical Education Professional)

Rodrigo Garcia Fiorillo 2,3,5 (D)

(Physical Education Professional)

Maycon Capoia da Silva 3,5 (ID)

(Physical Education Professional)

Guilherme dos Santos Amadeu1,3 (iD

(Physical Education Student)

Ágatha Graça2,5 (iD)

(Physical Education Professional)

Sérgio Luiz Carlos dos Santos 1,3 (iD

(Physical Education Professional)

Wilson Rinaldi ${ }^{3,6}$ (D)

(Physical Education Professional)
\end{abstract}

1. Centro Universitário de Tecnologia e Ciência do Norte do Paraná (UNIFATECIE), Paranavaí,

PR, Brazil.

2. Universidade Estadual do Paraná (UNESPAR), Paranavaí, PR, Brazil.

3. Centro Universitário de

Tecnologia e Ciência do Norte do Paraná (UNIFATECIE), Study and Research Group on Physical Education, health and performance (GPESDE), Paranavaí, PR, Brazil. 4. Clínica de Avaliação Nutricional Esportiva (CANE), Maringá,

PR, Brazil.

5. Universidade Estadual do Paraná (UNESPAR), Study and Research Group in Physical Fitness and Training (GEPAFIT), Paranavaí, PR, Brazil.

6. Universidade Estadual de Maringá (UEM), Postgraduate Program in Physical Education, Maringá, PR, Brazil.

\section{Correspondence:}

Rodrigo Garcia Fiorillo. Rua General Ciro Cardoso, 677, Nova Esperança, Paraná, Brazil. 87.600.000.

rodrigogarciafiorillo@hotmail.com

\begin{abstract}
Introduction:The COVID-19 pandemic has led to social isolation measures in different contexts. In endurance sports, competitions worldwide have been canceled, affecting behavioral, psychological, and physical aspects. Objective: This study aimed to assess potential associations between stress, motivation, behavioral changes, and physical fitness in endurance athletes, and time in social isolation. Methods: A cross-sectional study with the participation of 201 athletes, including mountain bikers $(n=89)$, runners $(n=88)$ and triathletes $(n=24)$. Each participant answered questions about time spent in isolation; body weight; changes in training schedule during the isolation period; levels of motivation; stress levels; loss of physical fitness; what aspect of physical fitness was most jeopardized during the isolation period; alcohol consumption; quality of sleep; quality of diet; and whether they had been ill during the isolation period. Results: The results showed significant differences between the percentage of runners (4.5\%) and triathletes (16.7\%) who had been isolated from 1-10 days, and between the percentage of cyclists (41.6\%) and runners (68.2\%) in 11-20 days and $>20$ days (28.1\% and $9.1 \%)$ respectively. Social isolation was significantly associated with at least one variable for the three groups of athletes; however, the runners were the most affected by the pandemic, presenting an association with low motivation, high stress, poorer quality of sleep, increased alcohol consumption, and loss of physical fitness. Conclusion: Our study showed that the period of social isolation, specifically over time $>10$ days, generated significant changes in the perceptions of motivation, stress, alcohol consumption, and physical fitness of endurance athletes, with runners being the most affected group. Level of Evidence III; Diagnostic studies - Investigation of a diagnostic test; Study of non-consecutive patients, without a "gold standard" applied uniformly.
\end{abstract}

Keywords: Athletes; Physical endurance; Coronavirus infections; Pandemics; Physical fitness.

\section{RESUMO}

Introdução: A pandemia de Covid-19 gerou medidas de isolamento social em diferentes contextos. Todas as competições de esportes de resistência foram canceladas em todo o mundo, portanto, os aspectos comportamentais, psicológicos e físicos podem ter sido afetados. Objetivo: Este estudo teve como objetivo avaliar possíveis associações entre estresse, motivação, mudanças comportamentais e aptidão física e o tempo de isolamento social em atletas de resistência. Métodos: Estudo transversal com participação de 201 atletas, entre ciclistas $(n=89)$ corredores $(n=88)$ e triatletas $(n=24)$. Cada participante respondeu perguntas sobre o tempo de isolamento; peso corporal; mudanças no cronograma de treinamento durante o período de isolamento; níveis de motivação; níveis de estresse, perda de aptidão física; qual aptidão física foi mais prejudicada no período de isolamento; consumo de álcool; qualidade do sono; qualidade da dieta e se ficou doente durante o período de isolamento. Resultados: Os resultados mostraram diferenças significantes entre a porcentagem de corredores (4,5\%) e triatletas (16,7\%) que ficaram isolados de 1 a 10 dias, entre ciclistas (41,6\%) e corredores (68,2\%) em 11 a 20 dias e mais de 20 dias $(28,1 \%$ e 9, 1\%), respectivamente. 0 isolamento social foi significativamente associado a pelo menos uma variável nos três grupos de atletas, porém, os corredores foram os mais afetados pela pandemia, apresentando associação a baixa motivação, alto estresse, pior qualidade do sono, aumento do consumo de álcool e perda da aptidão física. Conclusão: Nosso estudo mostrou que o perío do de isolamento social, especificamente com tempo de isolamento social superior a 10 dias, gerou mudanças significantes nas percepções de motivação, estresse, consumo de álcool e aptidão física de atletas de resistência, sendo os corredores o grupo mais afetado. Nível de evidência III; Estudos diagnósticos - Investigação de um exame para diagnóstico; Estudo de pacientes não consecutivos, sem "padrão de ouro" aplicado uniformemente.

Descritores: Atletas; Resistência física; Infecções por coronavírus; Pandemias; Aptidão física.

\section{RESUMEN}

Introducción: La pandemia de Covid-19 generó medidas de aislamiento social en diferentes contextos. Todas las competiciones de deportes de resistencia fueron canceladas en todo el mundo, por lo tanto, los aspectos comportamentales, psicológicos y físicos pueden haber sido afectados. Objetivo: Este estudio tuvo como objetivo evaluar posibles asociaciones entre estrés, motivación, cambios comportamentales y aptitud física y el tiempo de aislamiento 
social en atletas de resistencia. Métodos: Estudio transversal con participación de 201 atletas, entre ciclistas $(n=89)$, corredores $(n=88)$ y triatletas $(n=24)$. Cada participante respondió preguntas sobre el tiempo de aislamiento; peso corporal; cambio en el cronograma de entrenamiento durante el periodo de aislamiento; niveles de motivación; niveles de estrés, pérdida de aptitud física; qué aptitud física fue más perjudicada en el período de aislamiento; consumo de alcohol; calidad del sueño; calidad de la dieta y si estuvo enfermo durante el período de aislamiento. Resultados: Los resultados mostraron diferencias significativas entre el porcentaje de corredores $(4,5 \%$ ) y triatletas (16,7\%) que estuvieron aislados de 1 a 10 días, entre ciclistas (41,6\%) y corredores (68,2\%) en 11 a 20 días y más de 20 días $(28,1 \%$ y $9,1 \%)$ respectivamente. El aislamiento social fue significativamente asociado a por lo menos una variable en los tres grupos de atletas, sin embargo, los corredores fueron los más afectados por la pandemia, presentando asociación a baja motivación, alto estrés, peor calidad de sueño, aumento del consumo de alcohol y pérdida de la aptitud física. Conclusión: Nuestro estudio mostró que el período de aislamiento social, específicamente con tiempo de aislamiento social superior a 10 dias, generó cambios significativos en las percepciones de motivación, estrés, consumo de alcohol y aptitud física de atletas de resistencia, siendo los corredores el grupo más afectado. Nivel de Evidencia III; Estudios de diagnóstico: investigación de un examen para diagnóstico; Estudio de pacientes no consecutivos, sin "estándar de oro" aplicado uniformemente.

Descriptores: Atletas; Resistencia física; Infecciones por coronavirus; Pandemias; Aptitud física.

\section{INTRODUCTION}

The coronavirus disease (COVID-19) is a respiratory infection that has symptoms that include fever, cough, fatigue, and, in some cases, gastrointestinal infection. 'In more severe cases, it may cause pneumonia, pulmonary edema, acute respiratory distress syndrome, and multiple organ failure ${ }^{2}$, leading to death. COVID-19 is believed to have originated in bats, and its transmission to humans occurred through animals still unknown in Wuhan, China, in December 2019. ${ }^{3}$ Contamination occurs through the dispersion of droplets produced from coughing sneezing by symptomatic or asymptomatic individuals. ${ }^{4}$ These droplets, in turn, can be inhaled or deposited on surfaces that will be touched by the hands of others, who eventually touch their eyes, nose, or mouth. ${ }^{3}$ Thus, due to the rapid spread of the virus, in January 2020, the Chinese government suspended public transport and isolated Wuhan's city. ${ }^{5}$

People are encouraged to stay in their homes during isolation, avoid traffic through public places, and mainly do not gather in large groups. Besides, services considered non-essential for people's livelihood can be suspended, ${ }^{2}$ which includes postponing or canceling sporting events since the beginning of March 2020. ${ }^{6}$ In this scenario, Brazil has also been applying similar measures, including suspension of competitions of various sports, whether collective or individual, such as cycling and running. The Brazilian Cycling Confederation (CBC), following the International Cycling Union ( $\mathrm{UCl}$ ) and the Brazilian Olympic Committee and the Ministry of Health's recommendations, released an official statement suspending the calendar of national and international events held in Brazilian for 30 days. Subsequently, this organization extended the suspension until April 30, 2020, and may extend it if necessary. ${ }^{7,8}$

The suspension of competitions places athletes in the transition phase within their training or detraining period, where partial or complete loss of adaptations caused by training may be observed due to insufficient stimuli, ${ }^{9}$ reducing maximum and submaximal performance in aerobic exercises in a few weeks, coincident with impairments in cardiovascular function and metabolic muscle potential. ${ }^{10}$ During the transition period, cyclists show increases in body weight and decreases in VO2max and maximum power, ${ }^{11}$ while runners show decreases in VO2max and time to exhaustion, ${ }^{12}$ both of which are facts that may directly affect the physical fitness of these athletes.

In addition to the probable damage to physical fitness resulting from this "transition" period that athletes are experiencing due to the suspension of competitions, there is an aggravation of isolation factors that completely modify these individuals' routine. Thus, there is a hypothesis that athletes' levels of stress and motivation have changed the current situation, resulting in behavioral alterations in sleep and eating habits, indirectly reducing their physical fitness.

Given the above circumstances, this study aimed to assess potential associations among stress, motivation, behavioral changes, and fitness alterations resulting from time in social isolation. Furthermore, identification of the training variables (i.e., volume, intensity, and frequency) that underwent the most significant change in endurance athletes (cyclists, runners, and triathletes) during this period of "transition" will be determined.

\section{MATERIALS AND METHODS}

This cross-sectional study used an online questionnaire created on Google Forms platform, composed of 17 questions, including 13 multiple choices, and 4 open-ended questions to assess morphological, behavioral, psychological, and physical fitness parameters during athletes isolation due to the coronavirus pandemic. The research was framed in the context of a research question rather than a leading hypothesis. The online questionnaire was circulated to athletes through social networks and answered by the athletes between July 3 and July 6, 2020.

Participants were recruited online with the following inclusion criteria: (a) more than one year of experience of regular training; (b) training a minimum of 3 days and more than five hours per week; (c) experience in regional, national or international competitions; $(d) \geq 18$ years old. Thus, 201 athletes (143 men and 88 women) were included in the study and grouped as mountain bikers ( $n=89 ; 44.3 \%)$, runners ( $n=88 ; 43.8 \%)$, and triathletes $(n=24 ; 11,9 \%)$. All participants were informed in detail about the experimental procedures and the possible risks and benefits of their participation and provided written informed consent by clicking the "I agree" button before advancing to the questionnaire. According to the Declaration of Helsinki, this investigation was conducted and approved by the local University Ethics Committee (Process 3.767.270).

Each participant answered the questionnaire online, and all questions were mandatory, and submission of answer forms could be sent after all research questions were answered. The questions included in the questionnaire were as follows: 1) sex (male, female); 2) age; 3) time of isolation at home (0, 1-10 days, 11-20 days, > 20 days); 4) height; 5) body weight before isolation; 6) current body weight; 7) modality of practice (cycling, running, triathlon); 8) time of practice in the sport 
(1-2 years, 2-3 years, $>3$ years); 9) main change in training during the isolation period (intensity, weekly frequency, session time, no change); 10) level of motivation in the isolation period (high, medium, low); 11) level of stress in the isolation period (high, medium, low); 12) feelings of loss of physical fitness during the isolation period (yes, no); 13) what is the most sensitive sensation of loss in the isolation period (cardiorespiratory, muscular strength / resistance, flexibility, mobility, without weight loss); 14) alcohol consumption in the isolation period (increased, decreased, no change, I don't drink) 15) quality of sleep in the isolation period (worsened, improved, no change); 16) quality of food during the isolation period (worse, better, no change) 17) remained ill during the isolation period (yes, no).

Descriptive statistics were used to characterize athletes with values expressed as mean and standard deviation, relative frequency, and respective confidence intervals $\left(\mathrm{Cl}_{95 \%}\right)$. Potential statistical differences between the proportions of isolation period for motivation, stress, sleep, alcohol, food, physical fitness, and disease were analyzed using contingency tables, involving the non-parametric Chi-Square test $\left(x^{2}\right)$. One-way ANOVA tests were used to verify differences between groups for continuous variables, with Bonferroni post hoc tests used to explore significant differences. All analyses were performed using the Statistical Package for Social Science (SPSS Inc., Chicago, IL, USA), version 20.0.

\section{RESULTS}

Table 1 presents the anthropometric characteristics before and during social isolation and the time of practice of the modalities. The results show significant differences for age, height, body weight (before isolation), and practice time (1-2 years) for runners for cyclists and triathletes. Bodyweight during isolation showed a statistical difference between runners and cyclists. For the other variables, BMI, practice time of 2-3 years, and $>3$ years, the groups were similar.

Figure 1 shows the period in isolation that the athletes of each sport spent when answering the questionnaire. The results showed that, in general, 18.9\% $(n=38)$ of the athletes were not in social isolation, $8.5 \%$ $(n=17)$ were from $1-10$ days, $54.2 \%(n=109)$ of $11-20$ days and $18.4 \%$ $(n=37)$ were $>20$ days in social isolation. When comparing the modalities, there were significant differences in the $\%$ of athletes in each period between runners (4.5\%) and triathletes (16.7\%) in 1-10 days, between cyclists (41.6\%) and runners (68.2\%) in $11-20$ days and $>20$ days $(28.1 \%$ and $9.1 \%$ respectively).

Regarding the potential associations of social isolation with low motivation, high stress, worse quality of sleep, increased consumption of alcohol, worse quality of food, he became ill and felt a loss of physical fitness. The results showed that there was a significant association only for the variable"I got sick" ( $p=0.023)$ in the group of the cyclists, with the

Table 1. Anthropometric characteristics before and during social isolation and practice time of endurance athletes divided by modality $(n=201)$.

\begin{tabular}{|c|c|c|c|}
\hline \multirow{2}{*}{ Variables } & \multicolumn{3}{|c|}{ Mean \pm SD } \\
\hline & Cyclists $(\mathrm{n}=89)$ & Runners $(n=88)$ & Triathletes $(n=24)$ \\
\hline Age & $37.92 \pm 9.83$ & $43.73 \pm 9.34^{* \#}$ & $33.53 \pm 5.57$ \\
\hline Height $(\mathrm{cm})$ & $176.87 \pm 6.50$ & $165.18 \pm 8.80^{* \#}$ & $174.92 \pm 7.21$ \\
\hline Weight before $(\mathrm{kg})$ & $76.33 \pm 11.50$ & $64.73 \pm 16.01^{* \#}$ & $72.83 \pm 9.12$ \\
\hline During Weight $(\mathrm{kg})$ & $76.46 \pm 11.27$ & $65.64 \pm 17.27^{*}$ & $73.42 \pm 9.25$ \\
\hline BMI before $\left(\mathrm{Kg} / \mathrm{m}^{2}\right)$ & $24.32 \pm 2.84$ & $23.47 \pm 4.13$ & $23.71 \pm 1.74$ \\
\hline During BMI $\left(\mathrm{Kg} / \mathrm{m}^{2}\right)$ & $24.37 \pm 2.76$ & $23.79 \pm 4.57$ & $23.91 \pm 1.80$ \\
\hline Practice Time & \multicolumn{3}{|c|}{$\%\left(\mathrm{Cl}_{95 \%}\right)$} \\
\hline $1-2$ years $(n=17)$ & $14.6(8.3-22.9)$ & $0(0-2.2)^{*}$ & $16.7(5.5-34.6)$ \\
\hline $2-3$ years $(n=40)$ & $22.5(14.7-31.9)$ & $18.2(11.1-27.1)$ & $16.7(5.5-34.6)$ \\
\hline$>3$ years $(n=144)$ & $62.9(52.6-72.5)$ & $81.8(72.9-88.9)$ & $66.6(46.8-83.1)$ \\
\hline
\end{tabular}

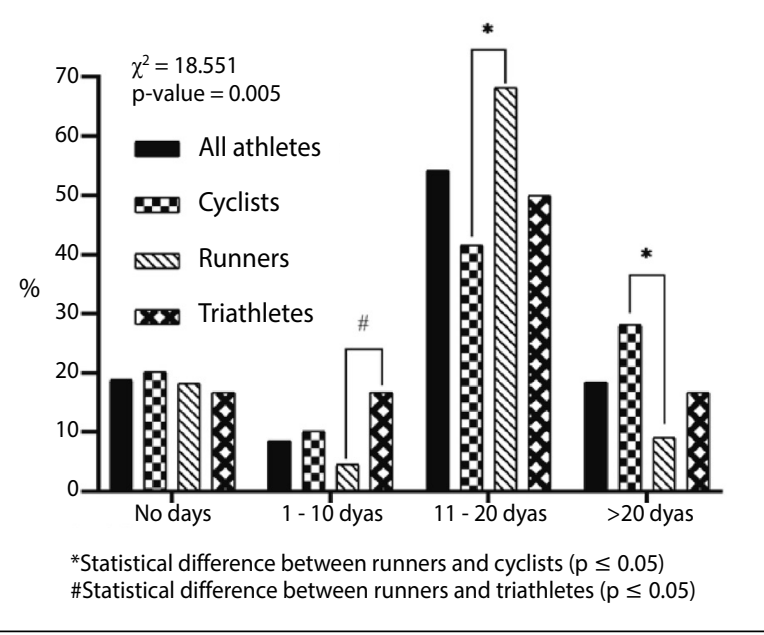

Figure 1. Isolation period in endurance athletes.

highest proportion of cases in those who reported not having been in social isolation. For the runners, the period of social isolation, specifically the period of 11-20 days, was statistically associated with low motivation $(p=0.007)$, high stress (0.019), worse sleep quality ( $p=0.032)$, increased consumption of alcohol ( $p=0.007)$, and loss of physical fitness ( $p=$ 0.002). In triathletes, significant associations were observed in the 11-20 days isolation period for reports of increased alcohol consumption ( $p=$ 0.001 ), and loss of physical fitness ( $p<0.001)$ and $>20$ days for reports of high stress $(p=0.002)$ and became ill ( $p=0.012$ ). (Table 2$)$

When dealing with the loss of physical fitness, the results showed that, in general, there was a significant difference $(p=0.002)$ between the groups, but, when analyzing each domain of physical fitness separately, only the cardiorespiratory fitness differed between the groups, specifically between cyclists and runners $(p=0.034)$. The results also showed that of the total sample ( $n=201)$, muscular strength/endurance was the most cited fitness among athletes (42.8\%), followed by cardiorespiratory fitness (22.9\%), mobility (2.5\%), and flexibility (1.0), that is, $69.2 \%$ reported a loss of any of the four skills.

In an attempt to explain changes in psychological, behavioral, and physical aspects during social isolation, the athletes indicated the variables that changed during this period. In general, the proportions of responses were statistically different among athletes $(p=0.001)$. In the case of treatment for each specific category, $8 \%$ of athletes reported that they did not suffer any changes in training, with cyclists being the group that had the highest percentage (13.5\%), which were statistically different from the percentages presented by triathletes $(0 \%)$ and runners (4.5\%). Regarding training changes, in general, a variable most often cited was training intensity (43.8\%), followed by weekly frequency (36.8\%), and session time (11.4\%), with significant differences ( $p \leq 0.05)$ in the weekly frequency change between cyclists (27.8\%) and triathletes (58.3\%), and session time between cyclists (19.1\%) and runners (4.5\%). When checking the delta variation in BMl among athletes, it showed a significant increase for the three modalities athletes, with a significant difference between runners and cyclists $(p=0.008)$. (Table 3$)$

\section{DISCUSSION}

The purpose of our study was to analyze associations between stress, motivation, behavioral changes, and physical fitness with time in social isolation and to identify which were the training variables (volume, intensity, and frequency) that presented the greatest changes in this period of "transition" on endurance athletes (cyclists, runners, and triathletes). Our significant findings were that 
Table 2. Frequency of strata of the period of social isolation according to the perception of the endurance athletes for different variables.

\begin{tabular}{|c|c|c|c|c|c|c|c|c|c|c|c|c|}
\hline \multirow{4}{*}{ Variables (\%) } & \multicolumn{12}{|c|}{ Isolation period } \\
\hline & \multicolumn{4}{|c|}{ Cyclists $(n=89)$} & \multicolumn{4}{|c|}{ Runners $(n=88)$} & \multicolumn{4}{|c|}{ Triathletes $(n=24)$} \\
\hline & \multicolumn{4}{|c|}{ Number of days } & \multicolumn{4}{|c|}{ Number of days } & \multicolumn{4}{|c|}{ Number of days } \\
\hline & 0 & 01-10 & $11-20$ & $>20$ & 0 & 01-10 & $11-20$ & $>20$ & 0 & $01-10$ & $11-20$ & $>20$ \\
\hline Low Motivation \# & 4.8 & 9.5 & 38.1 & 47.6 & - & - & 100.0 & - & 33.3 & - & 66.7 & - \\
\hline High Stress \#\# & 29.2 & 8.3 & 45.8 & 16.7 & 14.3 & - & 85.7 & - & 16.7 & - & 50.0 & 33.3 \\
\hline Sleep Quality Worsened \# & 25.0 & - & 50.0 & 25.0 & 16.7 & - & 83.3 & - & - & - & 66.7 & 33.3 \\
\hline Increased Alcohol Consumption \# & 5.9 & 11.8 & 41.2 & 41.2 & - & - & 100.0 & - & - & - & 100.0 & - \\
\hline Food Quality Worsened & 15.6 & 11.1 & 40.0 & 33.3 & 10 & - & 80.0 & 10 & 10.0 & 20.0 & 50.0 & 20.00 \\
\hline I got sick ${ }^{*} ¥$ & 50.0 & 20.0 & 30.0 & - & - & - & 100.0 & - & - & - & - & 100.0 \\
\hline Felt loss of physical fitness \#\# & 16.3 & 14.3 & 40.8 & 28.6 & 18.8 & - & 75.0 & 6.2 & - & 20.0 & 60.0 & 20.0 \\
\hline
\end{tabular}

* Statistical difference between cyclists; \# Statistical difference between runners; $¥$ Statistical difference between triathletes.

Table 3. Loss of physical fitness, changes in training and Body Mass Index in endurance athletes during social isolation.

\begin{tabular}{|c|c|c|c|}
\hline Variables & $\begin{array}{l}\text { Cyclists } \\
(n=89) \\
\end{array}$ & $\begin{array}{l}\text { Runners } \\
(n=88)\end{array}$ & $\begin{array}{c}\text { Triathletes } \\
(\mathrm{n}=\mathbf{2 4})\end{array}$ \\
\hline \multicolumn{4}{|c|}{ Perception of the loss of different physical fitness (\%) } \\
\hline Cardiorespiratory Fitness & $15.7^{*}$ & $31.8^{*}$ & 16.7 \\
\hline Muscular Strength / Resistance & 38.2 & 40.9 & 66.7 \\
\hline Mobility & 3.4 & 0.0 & 8.3 \\
\hline Flexibility & 2.2 & 0.0 & 0.0 \\
\hline
\end{tabular}

\begin{tabular}{c|c|c|c}
\hline \multicolumn{4}{|c|}{ Main change in training during the isolation period (\%) } \\
\hline Without Changes & $13.5^{*} ¥$ & $4.5^{*}$ & $0.0 ¥$ \\
\hline Intensiy & 40.4 & 50 & 33.3 \\
\hline Weekly Frequency & $27.0 ¥$ & 40.9 & $58.3 ¥$ \\
\hline Session Time & $19.1^{*}$ & $4.5^{*}$ & 8.3 \\
\hline
\end{tabular}

Delta variation in Body Mass Index (Mean $\pm \mathrm{SD})$ $\triangle \mathrm{BMI}\left(\mathrm{Kg} / \mathrm{m}^{2}\right)$ \begin{tabular}{|l|l|l|l|l}
$0.05 \pm 0.54^{*}$ & $0.32 \pm 0.66^{*} \#$ & $0.20 \pm 0.44 \#$ \\
\hline
\end{tabular} SD: Standard Deviation; BMI: Body Mass Index; *Statistical difference between cyclist and runners ( $\mathrm{p} \leq 0.05$ ) \#Statistical difference between triathletes and runners $(p \leq 0.05)$; $¥$ Statistical difference between cyclist and triathletes $(p \leq 0.05)$.

social isolation was significantly associated with all the variables for all the three groups of athletes. However, the runners group was the most affected by the pandemic, presenting association with low motivation, high stress, worst sleep quality, increased alcohol consumption, and loss of physical fitness.

In general, this isolation period might lead to inappropriate communication between athletes and their coaches, the absence of organized training and competition, hampers the ability to move freely, and inappropriate training conditions. ${ }^{13}$ Also, isolation at home may lead to poor and inappropriate nutrition, low quality of sleep, addictions, increase in body fat and a concomitant decrease in muscle mass, insomnia, and depression. ${ }^{13,14}$ Moreover, this forced isolation may be characterized as a detraining period, affecting different physiological systems, such as neuromuscular, cardiovascular, respiratory, and their corresponding physical capacities (muscular strength, and power, endurance, flexibility). ${ }^{15}$

Previous investigations have reported reductions in neuromuscular performance in just five weeks of training cessation, ${ }^{16}$ with some authors pointing out that 2 to 4 weeks are just enough to elicit performance loss. ${ }^{17}$ Aerobic performance, for example, may reduce within two to four weeks of detraining in competitive swimmers. ${ }^{18,19}$ In our study, around $23 \%$ of athletes reported perception of the loss of cardiorespiratory fitness, and most of them pointed the loss of physical fitness between 11-20 days, which coincide with the results aforementioned.

Regarding the increase in BMI in athletes, one possible explanation for this change might be related to the changes (reductions) in the training variables which are positively associated with the energy expenditure during and after a training session. ${ }^{20}$ Moreover, the differences in BMI found specifically between runners and cyclists and triathletes might be related to the fact that cyclists e triathletes usually have their bicycle roller for indoor training. In this case, they linked to software that simulates training conditions, specifically for cyclists, but for the runners, indoor training, having a treadmill might be a problem, due to the cost of this kind of equipment.

In our study, most of the athletes (92\%) reported changes in the training variables, such as intensity, weekly frequency, and session time during the isolation, which is a significant concern since it is complicated for coaches to guarantee that the athletes use the appropriate training load while exercising, especially at home. ${ }^{15}$ Although some sports clubs have an ideal structure to provide the athletes home-based training programs, this is not a reality for all of them, which, in turn, becomes an additional contributor to the damages from the social isolation. ${ }^{21}$ According to the data presented in Table 1, in our study, the period between 11-20 days and $>20$ days in isolation presented low motivation and sleep quality worsened in runners, high stress and increased alcohol consumption in runners and triathletes, which are variables related to psychological and behavioral domains. These negative changes might July 3rdted because of the lack of competition demotivating athletes to maintain their normal training routine, 15,22, not to mention the need for social isolation recommended by the government. The literature highlights the importance of continuing with a training routine to protect the athlete's mental health, especially attempting to reduce the risk of anxiety and depression. ${ }^{23}$

Thus, understanding the Impact of the COVID-19 pandemic on athletes is extremely crucial to create strategies to mitigate the effects of this disease on physical health and preserve the athletes' mental health. As recently highlighted by some researchers, several athletes had been focused on their preparation for international competitions. Upon this current situation, they might never have the chance to participate again, ${ }^{23}$ since the most important sports events in the world have been canceled or postponed. This change in their lives might trigger severe emotional problems in the future.

Our study has some limitations. We did not evaluate the dietary habits of the athletes. Future investigations should include other sports types, including several measures post-isolation period, to identify the real impact of this terrible moment the whole world is experiencing and propose appropriate approaches to cope with the innumerous negative changes that will probably come from this pandemic period.

Although the isolation period might promote several negative alterations, as observed in our study, some positive effects of this period are worthy of being mentioned. During these days, athletes can recover from the stress, injury, and mental stress imposed by the stimuli (training). Moreover, this critical moment is an opportunity for the athletes to improve other physical abilities that are not usually explored in a traditional periodization schedule. ${ }^{15,24}$ 


\section{CONCLUSION}

In conclusion, our study showed that the period of social isolation, specifically over time> 10 days, generated significant changes in the perception of motivation, stress, alcohol consumption, and physical fitness of endurance athletes, with runners being the most affected group. Such differences can be explained by the different changes in training variables and how each group can be trained during this period. In this sense, new studies that control the training variables and the use or not of ergometers or training rolls in periods of social isolation are necessary, as they can give a better redirection in the return of the athletes' activities.

All authors declare no potential conflict of interest related to this article

AUTHORS' CONTRIBUTIONS: Each author made significant individual contributions to this manuscript. FRG and MAN: design, analysis, data interpretation and writing; RGF, MCS and GSA: writing and critical review; AG, SLCS and WC: design and critical review. All authors reviewed and approved the final version of the manuscript.

\section{REFERENCES}

1. Guo YR, Cao QD, Hong ZS, Tan YY, Chen SD, Jin HJ, et al. The origin, transmission and clinical therapies on coronavirus disease 2019 (COVID-19) outbreak - an update on the status. Mil Med Res. 2020;7(1):11.

2. Chen N, Zhou M, Dong X, Qu J, Gong F, Han Y, et al. . Epidemiological and clinical characteristics of 99 cases of 2019 novel coronavirus pneumonia in Wuhan, China: a descriptive study. Lancet. 2020;395(10223):507-13.

3. Singhal T. A Review of Coronavirus Disease-2019 (COVID-19). Indian J Pediatr. 2020;87(4):281-6.

4. Rothe C, Schunk M, Sothmann P, Bretzel G, Froeschl G, Wallrauch C, et al. Transmission of 2019-nCoV Infection from an Asymptomatic Contact in Germany. N Engl J Med. 2020;382:970-1.

5. China. Circular da Sede de Prevenção e Controle da Pneumonia na Nova Infecção por Coronavírus em Wuhan. 1.2020

6. Toresdahl BG, Asif IM. Coronavirus Disease 2019 (COVID-19): Considerations for the Competitive Athlete. Sports health. 2020;12(3):221-4.

7. Confederação Brasileira de Ciclismo. Prorrogação de adiamento do calendário nacional; Suspensão dos Campeonatos Brasileiros de Pista e XCM. 1. 2020. [Access in??]. Available at: https://www.fpciclismo. org.br/index.php/2020/04/03/cbc-prorroga-adiamento-do-calendario-nacional/

8. Confederação Brasileira de Ciclismo. Suspensão do calendário nacional e o novo coronavírus (COVID-19). 1. 2020 [Access in??]. Available at: http://cbc.esp.br/noticias/busca/id/11225?fbclid=I wAR2PUSCD1foqInb_ZYqi_X5-sKsLnK4RgNT99xi7a8w1pxCuvhIGWFK-bAE.

9. Mujika I, Padilla S. Detraining: loss of training-induced physiological and performance adaptations. Part I: short term insufficient training stimulus. Sports Med. 2000;30(2):79-87.

10. Neufer PD. The effect of detraining and reduced training on the physiological adaptations to aerobic exercise training. Sports Med. 1989;8(5):302-20.

11. Maldonado-Martin S, Camara J, James DVB, Fernandez-Lopez JR, Artetxe-Gezuraga X. Effects of long-term training cessation in young top-level road cyclists. J Sports Sci. 2017;35(14):1396-401.

12. Houmard JA, Hortobágyi T, Johns RA, Bruno NJ, Nute CC, Shinebarger MH, et al. Effect of short-term training cessation on performance measures in distance runners. Int J Sports Med. 1992;13(8):572-6.
13. Chen P, Mao L, Nassis GP, Harmer P, Ainsworth BE, Li F. Wuhan coronavirus (2019-nCoV): The need to maintain regular physical activity while taking precautions. J Sport Health Sci. 2020;9(2):103-4.

14. Halabchi F, Ahmadinejad Z, Selk-Ghaffari M. COVID-19 epidemic: Exercise or not to exercise; that is the question! Asian J Sports Med. 2020;11(1):17-9.

15. Jukic I, Calleja-González J, Cos F, Cuzzolin F, Olmo J, Terrados N, et al. Strategies and Solutions for Team Sports Athletes in Isolation due to COVID-19. Sports (Basel). 2020;8(4):56.

16. García-Pallaris J, Sánchez-Medina L, Plrez CE, Izquierdo-Gabarren M, Izquierdo M. Physiological effects of tapering and detraining in world-class kayakers. Med Sci Sports Exerc. 2010;42(6):1209-14.

17. Sousa AC, Neiva HP, Izquierdo M, Cadore EL, Alves AR, Marinho DA. Concurrent Training and Detraining: brief Review on the Effect of Exercise Intensities. Int J Sports Med. 2019;40(12):747-55.

18. Neufer DD, Costill DL, Fielding RA, Flynn MG, Kirwan JP. Effect of reduced training on muscular strength and endurance in competitive swimmers. Med Sci Sports Exerc 1987;19(5):486-90.

19. Mujika I, Padilla S. Detraining: Loss of training-induced physiological and performance adaptations. Part II: Long term insufficient training stimulus. Sports Med. 2000;30(3):145-54.

20. Moghetti P, Bacchi E, Brangani C, Donà S, Negri C. Metabolic Effects of Exercise. Front Horm Res. 2016;47:44-57.

21. Sarto F, Impellizzeri F, Spörri J, Porcelli S, Olmo J, Requena B, et al. Impact of potential physiological changes due to COVID-19 home confinement on athlete health protection in elite sports: a call for awareness in sports programming. Sports Med. 2020;50(8):1417-9.

22. Mujika I, Halson S, Burke LM, Balagué G, Farrow D. An Integrated, Multifactorial Approach to Periodization for Optimal Performance in Individual and Team Sports. Int J Sports Physiol Perform. 2018;13(5):538-61

23. Hull JH, Loosemore M, Schwellnus M. Respiratory health in athletes: facing the COVID-19 challenge. Lancet Respir Med. 2020;8(6):557-8.

24. Silva JR, Brito J, Akenhead R, Nassis GP. The Transition Period in Soccer: A Window of Opportunity. Sports Med. 2016;46(3):305-13 